2723-7583 (Online)

\title{
ANALISIS KESESUAIAN HABITAT PENELURAN PENYU DI PANTAI SABA,
} GIANYAR, BALI

\author{
Analysis of Suitability of Beach Conditions for SeaTurtle Spawning on Saba Beach, Gianyar, Bali Under Guided

\section{Joanna Grace Mansula ${ }^{1 *}$ dan Agus Romadhon ${ }^{2}$} \\ ${ }^{1}$ Mahasiswa program Studi IImu Kelautan, Universitas Trunojoyo Madura \\ ${ }^{2}$ Dosen Program Studi IImu Kelautan, Universitas Trunojoyo Madura \\ ${ }^{*}$ Corresponding author email: joanna.gracemansula@gmail.com
}

Submitted: 05 February 2020 / Revised: 27 February 2020 / Accepted: 27 February 2020

http://doi.org/10.21107/juvenil.v111.6669

\begin{abstract}
One of the protected marine biota in Indonesia is sea turtles. This is because the number of sea turtle species in the world has been threatened with extinction. Because of it, sea turtle needs more attention from government and non-government agencies related to sea turtle in Indonesia. This concern can be in the form of research conducted to carry out sea turtle conservation. The conservation of sea turtles is very important to do to maintain the survival of sea turtles in their natural habitat so that the population of sea turtles does not decrease. The purpose of this research is 1) Know the quality of the waters at Serangan Beach and Saba Beach. 2) Analyze the suitability of Saba Beach for seaturtle conservation. 3) Identify important coastal factors for sea turtle conservation. This research was carried out structurally using a comparative method, namely comparing stations 1 and 2 where station 1 functions as an example station and station 2 as a test station. This study concludes that 1) the water quality on both coasts is in accordance with the standard quality standards for conservation areas according to Decree of the Minister of Environment number 51 of 2004, 2)Saba Beach is feasible to be used as a sea turtle conservation area and 3) a deterrent factor that makes both stations less well the appropriate conservation area is the presence of vegetation.
\end{abstract}

Keywords: Conformity analysis, Nesting ground, Seaturtle, Saba Beach

\section{ABSTRAK}

Salah satu biota laut yang dilindungi di negara Indonesia adalah penyu. Hal ini dikarenakan jumlah spesies penyu di dunia sudah mengalami ancaman kepunahan. Sehingga perlu perhatian lebih dari instansi pemerintah maupun non pemerintah terkait biota penyu yang ada di Indonesia. Perhatian tersebut dapat berupa penelitian yang dilakukan untuk melakukan konservasi penyu. Konservasi penyu sangat penting untuk dilakukan untuk menjaga keberlangsungan hidup penyu di habitat aslinya sehingga jumlah populasi penyu tidak semakin berkurang. Tujuan dari penelitian ini adalah untuk 1)Mengetahui kualitas perairan di Pantai Serangan dan Pantai Saba. 2)Menganalisa kesesuaian Pantai Saba untuk konservasi penyu.3)Mengidentifikasi faktor-faktor penting Pantai bagi pelestarian penyu. Penelitian ini dilakukukan secara terstruktur dengan menggunakan metode komparasi yaitu membandingkan stasiun 1 dan 2 dimana stasiun 1 berfungsi sebagai stasiun contoh dan stasiun 2 sebagai stasiun uji. Penelitian ini memperoleh kesimpulan jika kualitas perairan pada kedua pantai sudah sesuai dengan standart baku mutu untuk area konservasi menurut Keputusan Menteri Negara Lingkungan Hidup nomor 51 tahun 2004, Pantai Saba sudah layak untuk dijadikan area konservasi penyu dan faktor penghambat yang menjadikan kedua stasiun kurang baik untuk menjadi area konservasi yang sesuai adalah keberadaan vegetasi.

Kata kunci: Analisis Kesesuaian, Habitat Peneluran, Penyu, Pantai Saba

\section{PENDAHULUAN}

Penyu merupakan salah satu spesies dalam kelas reptil yang hidup di laut. Penyu memiliki kebiasaan dimana dia dirilis, atau menetas disitu pula lah dia akan kembali untuk bertelur. Penyu menghabiskan seluruh hidupya berada di laut akan tetapi induk penyu akan menuju ke daratan ketika waktunya bertelur. Hal ini menyebabkan penyu sangat sulit untuk dikonservasi. Status konservasi penyu secara Internasional sudah termasuk dalam daftar merah (Red List) di IUCN dan Appendix 1 CITES yang berarti keberadaannya di alam 
sudah terancam punah sehingga diperlukan suatu kegiatan konservasi guna melestarikan penyu.

Kegiatan pelestarian ini dimulai dari pelestarian area peneluran penyu, dimana area ini sangat penting bagi keberlangsungan pelestarian penyu. Salah satu lembaga konservasi penyu di Denpasar - Bali, berlokasi di Pulau Serangan yang bernama Turtle Conservation and Education Center. Sesuai dengan namanya TCEC melakukan kegiatan konservasi penyu di area Denpasar - Bali. Pulau Serangan, memiliki Pantai yang biasa digunakan untuk melakukan perilisan atau pelepasan penyu ke laut yang dilakukan di Pantai Serangan. Berdasarkan penelitian yang dilakukan oleh Anshary et al., (2014) Penyu memiliki kebiasaan, dimana ia dilepaskan disitu pula ia akan bertelur. Oleh karena itu Pantai Serangan banyak ditemukan telur penyu. Selain di Pantai Serangan terdapat pantai lain yang menjadi pendaratan bagi penyu untuk bertelur, yaitu Pantai Saba, di daerah Gianyar, Bali. Pada pantai Saba juga sering dilakukan perilisan penyu. Namun sarang yang ditemukan di pantai Saba masih lebih sedikit dibandingkan dengan jumlah sarang yang ditemukan di pantai Serangan.

Oleh karena itu penelitian ini dilakukan untuk mencari jawaban atas pertanyaan "MengapaPantai Saba masih jarang menjadi habitat peneluran penyu?" penelitian ini dilakukan dengan cara menganalisa beberapa parameter oseanografi untuk mengetahui kualitas perairan dari pantai saba dan menganalisa faktor-faktor yang berperan penting dalam habitat peneluran penyu. Tujuan dari penelitian ini antara lain: 1) Mengetahui kualitas perairan di Pantai Serangan dan Pantai Saba. 2) Menganalisis kesesuaian Pantai Saba untuk konservasi penyu. 3) Mengidentifikasi faktor-faktor penting habitat pelestarian penyu.

\section{MATERI DAN METODE}

Penelitian ini dilaksanakan di Pantai Serangan dan Pantai Saba pada tanggal 23 Juli 2018-2 Agustus 2018. Penelitian dilakukan dengan tiga tahap, dimana tahap pertama yaitu tahap pengambilan data lapangan dengan mengukur beberapa parameter kualitas perairan, suhu pasir sarang kemiringan pantai, serta pengambilan contoh pasir sarang. Tahap kedua adalah tahap pasca lapangan yaitu melakukan analisa secara deskriptif terhadap data yang diperoleh dilapangan yang kemudian ditampilkan dalam bentuk tabel, grafik dan histogram. Tahap ketiga adalah membandingkan hasil data yang diperoleh dari kedua stasiun penelitian yang kemudian disimpulkan karateristik Pantai sebagai habitat peneluran penyu.

\section{HASIL DAN PEMBAHASAN} Keadaan Umum Lokasi Penelitian

Lokasi yang digunakan dalam penelitian ini berada di dua stasiun atau dua pantai yang terletak di dua kabupaten yang berbeda yaitu kabupaten Gianyar dan Kota Denpasar. Stasiun yang pertama yaitu Pantai Serangan, pantai ini berada di pulau Serangan yang terletak di wilayah kecamatan Denpasar Selatan, Kota Denpasar, Provinsi Bali. Stasiun yang kedua yaitu Pantai Saba yang terletak di desa Saba Kecamatan Blahbatuh kabupaten Gianyar. Pantai ini berada disebelah Kanan By Pass Ida Bagus Mantra Gianyar Bali. Di pantai Saba terdapat salah satu instansi Konservasi di Gianyar Yaitu Saba Asri Turtle Conservation. Kedua pantai ini masih menjadi habitat peneluran Penyu. Sehingga kedua Instansi ini juga masih sangat aktif dalam perilisan tukik.

\section{Kualitas Perairan}

Kualitas dari suatu perairan juga mempengaruhi dari kenyamanan suatu biota untuk hidup disekitar perairan tersebut. Parameter kualitas perairan memiliki peranannya masing - masing seperti Suhu yang memiliki peranan penting karena penyu merupakan hewan poikilotermal yang berarti suhu tubuh mengikuti suhu lingkungan hingga batas tertentu. Air laut memiliki kisaran $\mathrm{pH}$ yang relatif stabil karena memiliki kemampuan untuk menjadi peyangga yang tinggi. Dalam suatu perairan oksigen terlarut juga memiliki peranan penting dimana oksigen terlarut memiliki peranan dalam reduksi bahan organik dan anorganik (Effendi, 2003). Sedangkan salinitas memiliki peranan dalam ketersediaan makanan bagi penyu pada perairan tersebut (Rohim et al., 2017). 
Tabel 1. Penilaian Parameter Kualitas Perairan

\begin{tabular}{|c|c|c|c|c|c|c|c|c|c|}
\hline \multirow{3}{*}{ No. } & \multirow{3}{*}{ Parameter } & \multicolumn{4}{|c|}{ Stasiun } & \multirow{3}{*}{$\begin{array}{l}\text { Rata- } \\
\text { rata }\end{array}$} & \multirow{3}{*}{ Kisaran } & \multirow{3}{*}{ Status } & \multirow{3}{*}{ Sumber } \\
\hline & & \multicolumn{2}{|c|}{1} & \multicolumn{2}{|c|}{2} & & & & \\
\hline & & $P$ & $S$ & $P$ & $S$ & & & & \\
\hline 1. & Suhu $\left({ }^{\circ} \mathrm{C}\right)$ & 26,4 & 27,7 & 26,5 & 27,7 & $27^{\circ} \mathrm{C}$ & $28-32^{0} \mathrm{C}$ & Sesuai & $\begin{array}{l}\text { KepMeNLH } \\
2004\end{array}$ \\
\hline 2. & $\begin{array}{l}\text { Derajat } \\
\text { Keasaman } \\
(\mathrm{pH})\end{array}$ & 7,9 & 8 & 7,5 & 7,8 & 7,8 & $7-8,5$ & Sesuai & $\begin{array}{l}\text { KepMeNLH } \\
2004\end{array}$ \\
\hline 3. & $\begin{array}{l}\text { Oksigen } \\
\text { terlarut } \\
\text { (mg/l) }\end{array}$ & 6,5 & 5,55 & 6,9 & 5,6 & $\begin{array}{l}6,13 \\
\mathrm{mg} / \mathrm{l}\end{array}$ & $>5 \mathrm{mg} / \mathrm{l}$ & Sesuai & $\begin{array}{l}\text { KepMeNLH } \\
2004\end{array}$ \\
\hline 4. & $\begin{array}{l}\text { Salinitas } \\
\text { (ppt) }\end{array}$ & 30,8 & 33,1 & 30,6 & 33,8 & $32 \mathrm{ppt}$ & $\begin{array}{l}33-34 \\
\text { ppt }\end{array}$ & Sesuai & $\begin{array}{l}\text { KepMeNLH } \\
2004\end{array}$ \\
\hline
\end{tabular}

\section{Suhu}

Suhu merupakan salah satu parameter yang penting dalam suatu perairan. Karena suhu dapat mempengaruhi aktivitas makhluk hidup. Misalnya pada proses metabolisme yang akan mengalami peningkatan seiring dengan kenaikan suhu. Setiap adanya perubahan suhu, juga akan cenderung mempengaruhi banyak atau sedikitnya proses kimiawi pada biota laut. Suhu dipengaruhi oleh sinar matahari yang terserap kedalam perairan. Panas yang terserap kedalam air ini juga akan mengalami perubahan secara perlahan antara siang dan malam hari. Suhu pada suatu perairan dapat dipengaruhi oleh musim, ketinggian permukaan laut, penutupan awan, aliran dan kedalaman air. Peningkatan atau penurunan suhu dapat berpengaruh terhadap viskositas, reaksi kimia dan evaporasi. Kisaran suhu air yang sangat diperlukan untuk pertumbuhan biota laut pada perairan tropis dapat berlangsung berkisar antara $25-32^{\circ} \mathrm{C}$ Menurut Ario et al., (2016) penyu lebih menyukai perairan yang cenderung hangat yang memiliki rentan suhu sekitar $28-32^{\circ} \mathrm{C}$. Berdasarkan Tabel 4.2 suhu di stasiun 1 dan 2 pada pagi hari berkisar antara $26^{\circ} \mathrm{C}-27 \mathrm{C}$ dimana itu masih termasuk dalam rentang suhu yang hangat dalam suatu perairan, sedangkan pada sore hari suhu perairan di stasiun 1 dan 2 memiliki rentang sekitar $27^{\circ} \mathrm{C}-30^{\circ} \mathrm{C}$ rentang suhu ini juga terbilang lebih hangat dibandingkan dengan suhu dipagi hari. Selain daripada hal itu Susana, (2009) mengatkan bahwa variasi suhu yang terjadi pada suatu perairan juga dipengaruhi oleh adanya proses bioma melalui mikroorganisme yang dapat menghasilkan panas dalam reaksi endotermik dan eksotermik dan juga proses mikrobiologis.

\section{Potensial of hydrogen $(\mathrm{pH})$}

Derajat keasaman atau potensial of hydrogen $(\mathrm{pH})$ merupakan salah satu hal penting dalam menentukan kualitas air pada suatu perairan. $\mathrm{pH}$ umumnya mengalami peningkatan akibat dari perairan yang sudah tercemar. Menurut Simanjuntak, (2012) sebagian besar biota akuatik sensitif terhadap perubahan derajat keasaman $(\mathrm{pH})$ pada suatu perairan. Biota akuatik umumnya menyukai kondisi perairan dengan $\mathrm{pH}$ sekitar $7-8,5$ hal ini disebabkan karena nilai $\mathrm{pH}$ Berdasarkan Tabel 4.1 terlihat hasil pengukuran dari $\mathrm{pH}$ suatu perairan menurut Keputusan Menteri Negara Lingkungan Hidup berkisar antara 7,8 - 8 dimana hal ini berarti kualitas perairan pada kedua stasiun terbilang cukup baik dan ideal bagi organisme laut baik mikroorganisme ataupun makroorganisme. Hal ini juga memiliki arti bahwa persediaan pakan alami bagi penyu terbilang cukup baik karena kualitas perairan yang dimiliki oleh kedua stasiun tersebut memiliki kualitas yang baik dan ideal untuk organisme laut.

\section{Oksigen Terlarut (Dissolved Oxygen)}

Menurut Booth et al., (2004) semakin banyak jumlah oksigen dalam suatu perairan, maka kualitas dari perairan tersebut juga semakin baik. Oksigen terlarut juga dibutuhkan oleh semua makhluk hidup dalam suatu perairan untuk proses metabolisme atau pertukaran zat yang kemudian akan diolah dan menghasilkan energi untuk pertumbuhan dan pembiakan, selain daripada itu oksigen juga diperlukan dalam mereduksi bahan - bahan organik dan anorganik dalam proses aerobik. Berdasarkan Tabel 1. nilai oksigen terlarut (DO) pada pantai Serangan saat pagi hari sebesar $6,5 \mathrm{mg} / \mathrm{l}$, sedangkan pada sore hari sebesar $5,55 \mathrm{mg} / \mathrm{l}$. Pada pantai Saba nilai oksigen terlarut pada pagi hari sebesar $6,9 \mathrm{mg} / \mathrm{l}$ dan pada sore hari sebesar 5,6 mg/l. Menurut Effendi, (2003) perbedaan ini disebabkan oleh aktivitas dari mikroorganisme untuk mengurai zat organik maupun anorganik. Kementerian lingkungan hidup menetapkan nilai ambang batas untuk 
kehidupan biota laut sebesar $\geq 5 \mathrm{mg} / \mathrm{l}$. Berdasarkan ketetapan tersebut kadar oksigen terlarut pada 2 stasiun berada dalam keadaan baik karena memiliki kadar lebih dari $5 \mathrm{mg} / \mathrm{l}$ pada pagi maupun sore hari. Menurut Effendi (2003) konsentrasi DO diperairan mengalami fluktuasi seara harian dan musiman yang bergantung pada proses penampuran massa air, aktifitas fotosintesis, respirasi dan masukan limbah.

\section{Salinitas}

Salinitas air laut merupakan jumlah kadar garam yang terkandung pada air laut. Salinitas memiliki pengaruh terhadap kehidupan organisme pada suatu perairan. Setiap perairan memiliki kadar salinitas yang berbeda. Salinitas memiliki peranan penting dalam kehidupan dari suatu biota pada suatu perairan. menurut Susana, (2009) air laut secara alami merupakan air saline dengan kandungan garam sekitar $32-35$ ppt. Salinitas air laut memiliki kaitan dengan ketersediaan stok pangan di perairan guna pakan alami dari penyu tersebut. Hal ini dikarenakan biota laut lebih banyak hidup di perairan yang memiliki perubahan salinitas rendah (Simanjuntak, 2012). Perbedaan salinitas inipun dapat disebabkan oleh adanya pengadukan dalam laut yang ditimbulkan oleh adanya gelombang laut maupun pergerakan massa air yang disebabkan oleh tiupan angin. Salinitas yang baik pada suatu perairan adalah sekitar $32-35$ ppt.
Adapun faktor - faktor yang mempengaruhi perubahan salinitas air laut menurut Arianto, (2014) yaitu: 1) penguapan, dimana penguapan berbanding lurus dengan salinitas air laut; 2) curah hujan, dimana curah hujan memiliki perbandingan yang terbalik dengan salinitas, apabila urah hujan tinggi maka salinitasnya rendah; 3) kelembaban udara: hal ini berhubungan dengan besar kecilnya penguapan yang berbanding lurus dengan besar kecilnya salinitas air laut. Berdasarkan pada Tabel 1. salinitas pada stasiun 1 dan 2 diwaktu pagi hari memiliki rentang $30-31$ ppt dimana kadar tersebut terbilang tidak cukup baik untuk suatu perairan, sedangkan pada sore hari salinitas di stasiun 1 dan 2 memiliki rentang sekitar 33 - 34 ppt. Kadar salinitas ini terbilang cukup tinggi namun masih termasuk dalam batas wajar dari suatu perairan yang baik. Alasan Perbedaan salinitas pada pagi dan sore hari ini masih belum di temukan secara pasti.

\section{Parameter Kesesuaian Habitat Peneluran Penyu}

Parameter kesesuaian habitat penyu terdiri dari beberapa parameter dengan nilai berbeda. Parameter tersebut diantaranya panjang dan lebar pantai, kemiringan pantai, pasang surut pantai, kedalaman sarang, Ukuran butir pasir, suhu kedalaman dan permukaan sarang, suasana pantai, abrasi pantai dan banyaknya vegetasi pada pantai tersebut. Adapun hasil dari penilaian parameter habitat penyu pada pantai Serangan dan Pantai Saba ditampilkan pada Tabel 1.

Tabel 2. Penilaian Parameter Kesesuaian Habitat Peneluran Penyu

\begin{tabular}{|c|c|c|c|c|c|}
\hline \multirow{2}{*}{ No. } & \multirow{2}{*}{ Parameter } & \multicolumn{2}{|c|}{ Stasiun } & \multirow{2}{*}{ Kisaran } & \multirow{2}{*}{ Sumber } \\
\hline & & 1 & 2 & & \\
\hline 1. & Panjang Pantai (Meter) & 965 & 1.026 & $867 \mathrm{~m}$ & Khaisu 2014 \\
\hline 2. & Lebar Pantai (Meter) & 19,7 & 31,5 & $20-80 m$ & $\begin{array}{l}\text { Manthenge } \\
2012\end{array}$ \\
\hline 3. & Kemiringan Pantai $\left(^{\circ}\right)$ & 13,3 & 13,1 & $\pm 30^{\circ}$ & Nuitja 1992 \\
\hline 4. & Pasang Surut (cm) & 40 & 40 & $30-80 \mathrm{~cm}$ & - \\
\hline 5. & Substrat & $\begin{array}{l}96 \% \text { pasir } \\
\text { Sedang }\end{array}$ & $\begin{array}{l}96 \% \text { pasir } \\
\text { Sedang }\end{array}$ & $90 \%$ pasir & Nuitja 1992 \\
\hline 6. & Kedalaman Sarang (cm) & 30 & 30 & $\begin{array}{c}30-80 \\
\mathrm{~cm}\end{array}$ & Bustard 1972 \\
\hline 7. & $\begin{array}{ll}\text { Suhu } & \text { Permukaan } \\
\text { Sarang }\left({ }^{\circ}\right) & \\
\end{array}$ & 26,9 & 27,3 & $24-32^{0}$ & Miller 1997 \\
\hline 8. & $\begin{array}{l}\text { Suhu Kedalaman } \\
\text { Sarang }\left({ }^{\circ}\right)\end{array}$ & 30,7 & 30,9 & $30-32^{0}$ & $\begin{array}{c}\text { Ackherman } \\
1997\end{array}$ \\
\hline 9. & Abrasi Pantai $\left(\mathrm{m}^{2}\right)$ & 8.875 & 20.203 & 500.000 & Parman 2017 \\
\hline 10. & Vegetasi Pantai (in/ha) & - & - & $\begin{array}{l}1.500 \\
\text { in/ha }\end{array}$ & - \\
\hline 11. & Suasana Pantai & Sepi & Ramai & Sepi & Manurung 2015 \\
\hline
\end{tabular}

Ket: Stasiun 1= Pantai Serangan, Stasiun 2= Pantai Saba 


\section{Panjang dan lebar pantai}

Panjang dan lebar dari suatu pantai memiliki pengaruh terhadap penyu dalam aktivitasnya untuk pembuatan sarang. Penyu memiliki keenderungan untuk memilih lokasi pantai yang luas dengan panjang dan lebar pantai yang sempit. Menurut Booth et al., 2004 penyu akan lebih mudah dalam menentukan lokasi peneluran apabila garis pantainya panjang, sehingga terdapat area yang cukup luas dalam melakukan observasi atau meyakinkan diri bahwa lokasi peneluran sudah cukup aman dan jauh dari predator, sedangkan lebar pantai yang sempit akan mempermudah induk penyu untuk kembali ke perairan setelah melakukan proses peneluran.

Menurut Setiawan et al., (2018), lebar pantai memiliki korelasi terhadap luas tempat yang dapat digunakan untuk penyu membuat sarang dan bersarang. Hasil pengukuran panjang garis pantai dan lebar pantai pada ketiga stasiun telah ditampilkan pada tabel 2. dimana panjang pantai pada stasiun 1 atau pantai serangan sepanjang $965 \mathrm{~m}$ dengan lebar pantai selebar 19,7 m. Sedangkan panjang pantai pada stasiun 2 sepanjang $1024 \mathrm{~m}$ atau sekitar $1 \mathrm{~km}$ dengan lebar pantai selebar 31,5 meter. Berdasarkan Tabel 2. panjang pantai pada kedua stasiun sudah sangat memenuhi syarat parameter kesesuaian habitat peneluran penyu karena menurut Khaisu, (2014) panjang garis pantai yang baik untuk habitat peneluran penyu berkisar $867 \mathrm{~m}$. Semakin panjang garis pantai maka penyu akan semakin mudah untuk memilih lokasi peneluran. Lebar pantai pada kedua stasiun diketahui berada pada kisaran $19 \mathrm{~m}$ hingga $31 \mathrm{~m}$, lebar pantai ini terbilang cukup sempit karena menurut Manthenge et al. (2012) lebar pantai yang ideal untuk dijadikan lokasi peneluran penyu berkisar antara $20-80$ $\mathrm{m}$.

\section{Kemiringan pantai}

Kemiringan pantai merupakan salah satu faktor yang paling berpengaruh dalam peneluran penyu. Hal ini disebabkan karena kemiringan pantai berpengaruh terhadap naiknya induk penyu ke pantai. Kemiringan pantai yang disukai penyu adalah pantai yang memiliki kemiringan landai, karena sangat berpengaruh pada aksesbilitas penyu untuk menapai daerah yang cocok untuk bertelur karena semakin curam kemiringan suatu pantai maka akan menyebabkan penyu kesulitan untuk mencapai area supratidal (Setiawan \& Zamdial, 2018). Berdasarkan Tabel 2. Pantai Saba dan Pantai Serangan memiliki kisaran kemiringan yang hampir sama, yang berkisar antara 13,1 $13,3^{\circ}$.

Kemiringan pantai memiliki pengaruh yang signifikan terhadap aktivitas penyu dalam melakukan pendaratan ke area peneluran atau pantai itu sendiri. Curam atau landainya suatu pantai akan mempengaruhi banyak dan sedikitnya jumlah penyu yang naik kepermukaan untuk melakukan peneluran karena hal ini juga akan berbanding lurus dengan energi yang digunakan untuk penyu supaya dapat naik ke pantai (Anshary et al., 2014) Pemilihan lokasi pantai dengan kemiringan tertentu diduga memiliki tujuan untuk mengamankan sarang dari genangan air laut pada saat pasang tertinggi. Sehingga kemungkinan untuk telur penyu gagal menetas sangat minim. Menurut Akerman, (1997) dalam Zakyah, (2016) genangan air laut pada saat pasang tertinggi dapat mempengaruhi kelembaban dari sarang yang seara langsung juga dapat mempengaruhi aktivitas metabolisme dari embrio yang sedang berkembang.

\section{Pasang Surut}

Pasang surut air laut merupakan salah satu faktor yang memiliki pengaruh sangat penting dalam proses pendaratan penyu di suatu pantai pada masa - masa peneluran penyu. Pasang surut air laut juga mempengaruhi indukan penyu dimana mereka akan menggali sarang untuk melakukan peneluran dipantai dan meninggalkan telur - telur mereka sampai tiba saatnya ntuk menetas. Pengukuran pasang surut yang digunakan dimulai pada tanggal 23 Juli - 23 Agustus 2018 dengan mengambil data dari website tides.big.go.id yang kemudian diolah menggunakan perhitungan admiralty dan ditampilkan dalam grafik. Adapun grafik pasang surut di pantai Serangan dan pantai pantai Saba pada bulan juli - agustus 2018 dapat dilihat pada Gambar 1 dan 2 


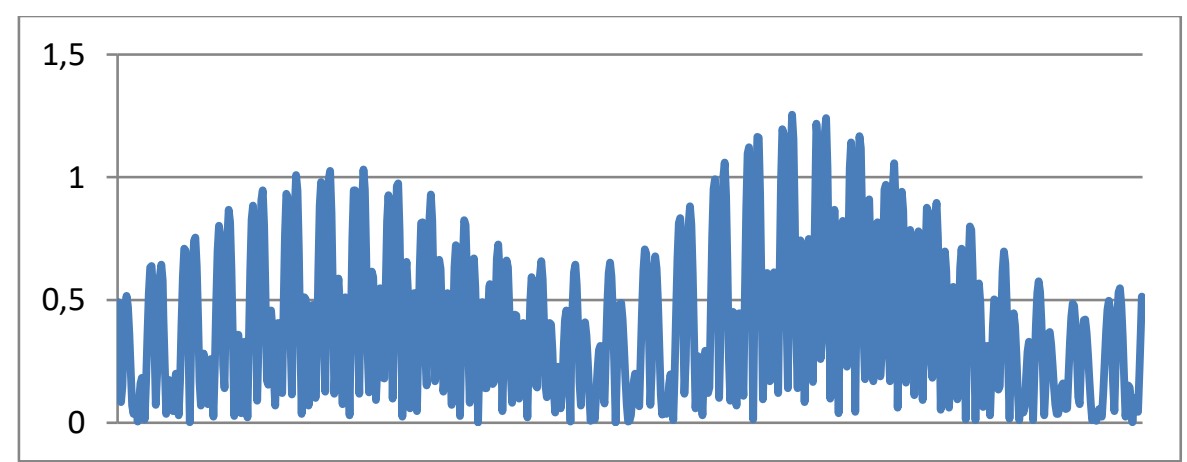

Gambar 1. Pasang surut di Pantai Serangan periode 23 Juli - 23 Agustus 2018

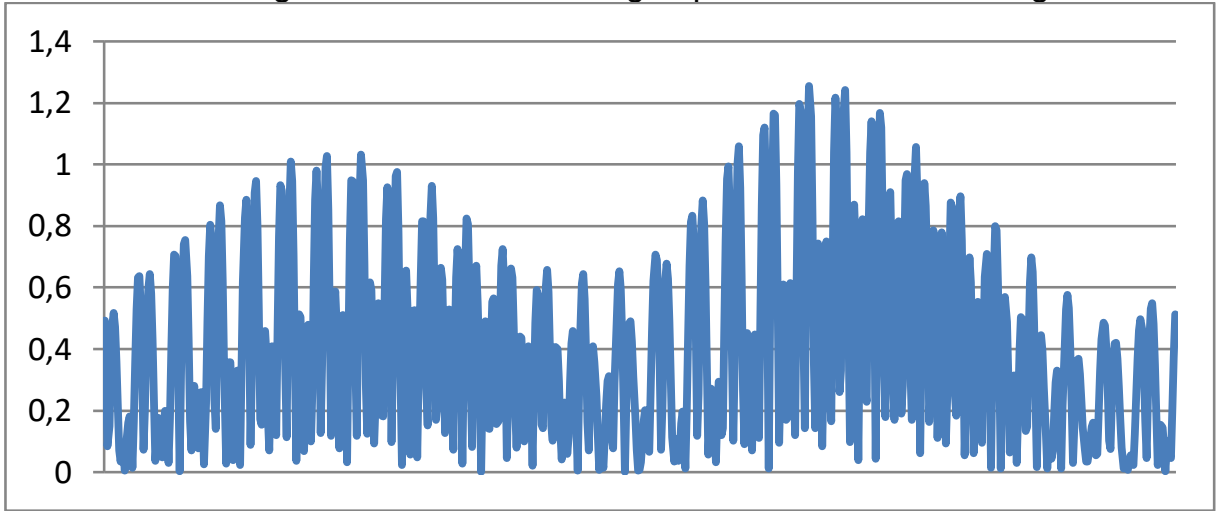

Gambar 2. Pasang surut di Pantai Saba periode 23 Juli - 23 Agustus 2018

Berdasarkan Gambar 1 dan 2 terlihat bahwa tipe pasang surut di Pantai Serangan dan Pantai Saba adalah tipe semi diurnal dimana terjadi dua kali pasang dan dua kali surut dalam sehari semalam. Lebih lanjut, mean sea level dari stasiun 1 dan pada stasiun 2 terdapat kemiripan yaitu sebesar 0,4 $\mathrm{m}$ atau setara dengan $40 \mathrm{~cm}$. Adapun surut terendah pada stasiun 1 dan pada stasiun 2 sebesar $0,1 \mathrm{~m}$ atau setara dengan $10 \mathrm{~cm}$ dan pasang tertingginya dapat mencapai 1,2 m atau setara dengan $120 \mathrm{~cm}$. Kemiripan yang terjadi ini mungkin disebabkan karena perairan Saba dan Perairan Serangan terdapat di daerah yang sama atau di area perairan selatan pulau Bali. Pasang surut berperan untuk membantu penyu saat naik ke daratan, pada umumnya penyu mulai naik satu atau dua jam sebelum dan sesudah pasang tertinggi malam itu, hal ini digunakan oleh induk penyu untuk menghemat energi (Mukminin, 2002). Selain daripada itu pasang surut juga mempengaruhi indukan penyu untuk menentukan lokasi peneluran karena indukan penyu akan memilih lokasi yang aman dan jauh dari pasang tertinggi guna menghindari tergenangnya sarang dengan air yang akan mengakibatkan telur gagal menetas (Nuitja \& Uchida, 1982).

\section{Substrat}

Menurut Ridwan et al., (2018) tekstur substrat sarang akan mempengaruhi proses penggalian sarang. Umumnya penyu tidak menyukai kondisi pasir yang sangat halus karena sangat mempersulit penyu dalam menggali sarang dan dapat menyebabkan sarang yang digali menjadi mudah longsor, penyu juga tidak menyukai kondisi pantai yang memiliki kondisi substrat yang sangat kasar karena dapat melukai tubuh penyu. Menurut Novitawati et al., (2003) karakteristik pantai yang disukai penyu adalah pantai yang memiliki pasir sedang dengan hamparan yang luas dan landai. Berdasarkan hasil analisa yang dilakukan kedalam 4 sampel yang diambil dalam kedua stasiun dalam 2 sarang yang sering ditemukan telur yang telah tercantum dalam Tabel 4.2 hasil yang diperoleh yaitu pada kedua stasiun jenis substratnya terakumulasi 99,6\% pasir dan $0.4 \%$ debu, namun secara kasat mata pasir yang terdapat di stasiun 1 lebih kasar dibanding degan pasir yang berada di stasiun 2 namun setelah dianalisa pasir pada kedua stasiun memiliki jenis pasir yang sedang.

\section{Sarang}

Penelitian terkait kesesuaian sarang terhadap penyu mencakup tiga parameter yaitu suhu permukaan sarang, suhu kedalaman sarang, dan kedalaman sarang. Salah satu faktor yang mempengaruhi dalam proses peneluran dan inkubasi telur penyu adalah suhu pasir baik dipermukaan maupun didalam sarang. Suhu sarang akan mempengaruhi perkembangan dan metabolisme embrio dari penyu tersebut, karena perkembangan dan metabolism embrio 
akan terganggu apa bila suhu sarang melebihi batas toleransi dari telur penyu. Menurut Putera et al., (2015) kisaran suhu normal untuk sarang penyu berkisar antara $24^{\circ} \mathrm{C}-32 \mathrm{C}$. Berdasarkan Tabel 2 suhu dari permukaan sarang di pantai serangan sekitar $26,9^{\circ} \mathrm{C}$ dan suhu di dalam sarang dengan kedalaman $30 \mathrm{~cm}$ sebesar $30,7^{\circ} \mathrm{C}$ lebih hangat dibandingkan dengan sehu permukaan sarang, Pada pantai Saba suhu permukaan sarang sebesar $27,3^{\circ} \mathrm{C}$ dan suhu didalam sarang sebesar $30,9^{\circ} \mathrm{C}$, proses inventarisir data dilakukan pada pukul yang sama dihari yang berbeda hal yaitu pada pukul 16.00 WITA. Perbedaan suhu ini dipengaruhi oleh banyaknya cahaya matahari yang diterima dipermukaan pasir yang kemudian dirambatkan dan diserap oleh lapisan pasir yang lebih dalam (Rofiah et al., 2012). Broderick et al. (2000) dalam Merwe, (2006) mengungkapkan bahwa kedalaman sarang dapat mempengaruhi suhu sarang sehingga sarang menjadi stabil. Umumnya penyu membuat sarang secara alami dengan kedalaman $30-70 \mathrm{~cm}$. Namun berdasarkan penelitian yang dilakukan oleh Putera et al., (2015) sarang yang memiliki suhu paling stabil memiliki kedalaman $70 \mathrm{~cm}$ dan kedalaman sarang yang memiliki suhu yang paling tidak stabil adalah $30 \mathrm{~cm}$. Lebih lanjut, berdasarkan Tabel 2 kedalaman sarang buatan yang dibuat di area konservasi sedalam $30 \mathrm{~cm}$, hal ini dapat dikatakan cukup berbahaya karena kemungkinan untuk telur penyu dapat menetas dengan baik terbilang minimal. Namun berdasarkan keadaan dilapang yang telah dilakukan oleh pihak konservasi TCEC dan Saba Asri Turtle Conservation keberhasilan penetasan dengan sarang.

\section{Abrasi Pantai}

Menurut Supriyanto, 2003 dalam Damaywanti 2013 mengatakan bahwa abrasi adalah proses pengikisan pantai yang disebabkan oleh gelombang dan arus laut dan bersifat destruktif. Abrasi dapat disebabkan oleh gejala alami, namun aktivitas manusia di pesisir juga memiliki andil dalam proses terjadinya abrasi, salah satunya adalah kegiatan penebangan vegetasi mangrove di pesisir pantai. Perubahan wilayah pesisir terutama garis pantai dapat diketahui dengan menggunakan metode penginderaan jauh. Data citra satelit yang digunakan dalam analisa adalah data citra landsat 7 dan 8 pada tahun 2002 dan 2018 . Hasil yang diperoleh dari pengolahan data tersebut dianalisa secara kuantitatif yang kemudian diimpretasikan dalam bentuk peta abrasi garis pantai.

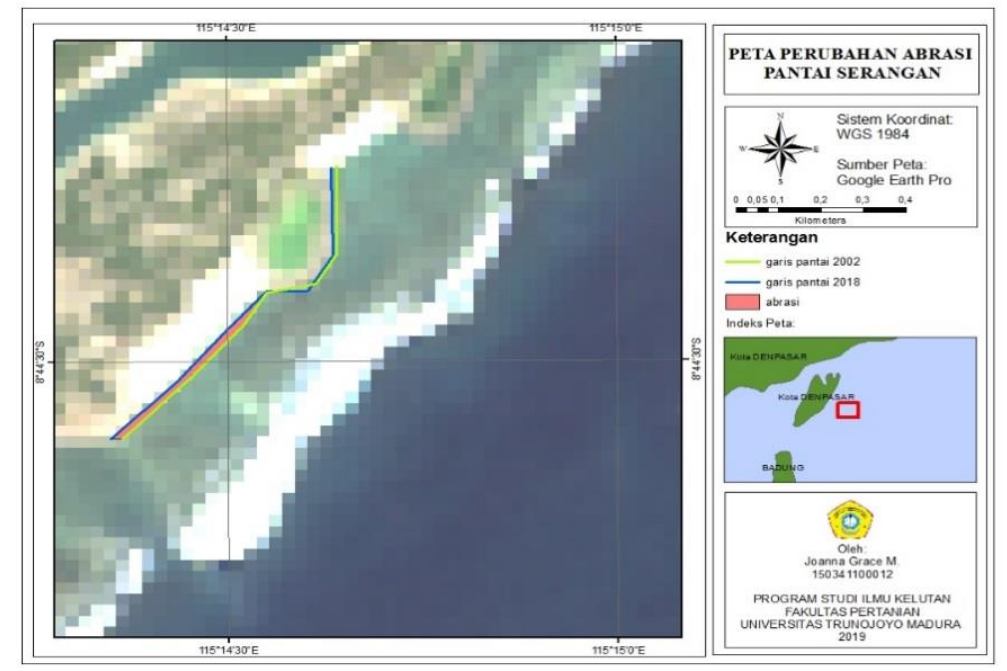

Gambar 3. Peta perubahan garis pantai dan abrasi pantai Serangan 


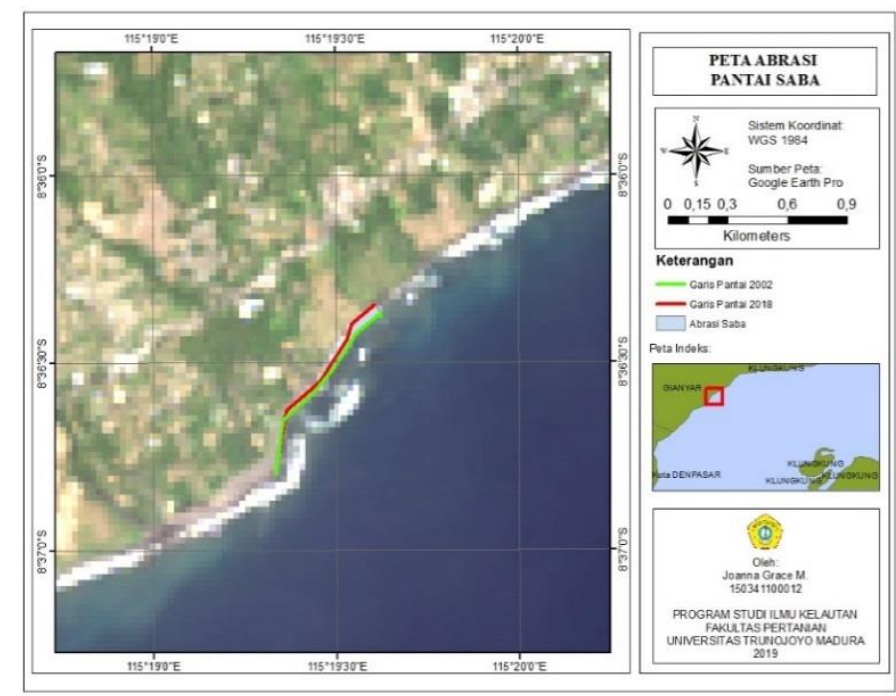

Gambar 4. Peta perubahan garis pantai dan abrasi pantai Saba

Berdasarkan Gambar 2 dan Gambar 4. hasil interpretasi dan klarifikasi dari citra Landsat 7 ETM, diperoleh hasil perubahan garis pantai yang cukup signifikan dari tahun 2002 sampai 2018 pada kedua stasiun. Pada stasiun 1 sejak tahun 2002 hingga 2018 mengalami abrasi seluas $8875 \mathrm{~m}$ dan pada stasiun 2 mengalami abrasi seluas $20203 \mathrm{~m}^{2}$. Pengamatan secara langsung dilaksanakan melalui observasi secara langsung dan melakukan wawancara kepada masyarakat sekitar. Survei lapangan bertujuan untuk mencocokan kenampakan yang hasil interpretasi data citra. Sejak tahun 2002 hingga tahun 2018 kedua stasiun lebih banyak mengalami abrasi daripada akresi.

\section{Vegetasi Pantai}

Menurut Sepawan, (2017) vegetasi pantai adalah tumbuhan yang sering ditemukan didaerah intertial atau pasang surut. Salah satu faktor penting untuk berbagai jenis penyu dalam melakukan peneluran adalah hutan pantai yang didukung oleh naungan vegetasi yang didominasi oleh pandan (Pandanus tectorius). Jenis vegetasi pantai umumnya ditemukan di sepanjang lokasi peneluran penyu berupa tumbuhan pioner atau tumbuhan perintis yang mengisi lahan kosong seperti Hibisus tiliaceus (Waru), Gynura proumbens (Tanaman sambung nyawa), Hernandia peltata (Klampis cina), Pandanus (Pandan), Cocos nucifera (kelapa), Casuarina equisetifolia (cemara laut) dan lainnya. Menurut Ridwan et al., (2017), vegetasi pada suatu pantai memiliki fungsi yang cukup penting bagi area peneluran penyu karena hal ini berhubungan dengan naluri indukan penyu dalam melindungi dan menjaga telur - telurnya. Selain itu peranan dari vegetasi adalah berguna menjaga kestabilan suhu akibat sinar matahari agar kenaikan yang terjadi tidak terlalu ekstrim Daya serap pasir terhadap sinar matahari langsung terbilang cukup baik terutama pasir yang berwarna gelap sampai dengan hitam. Beberapa sarang yang ditemukan di suatu pantai umumnya berada dibawah naungan vegetasi, hal ini diperkirakan karena akar vegetasi dapat memiliki peranan untuk mengikat butiran pasir sehingga dapat menjaga agar tidak terjadi kelongsoran pasir yang dapat menyebabkan kegagalan penetasan pada stasiun 1 dan stasiun 2 tidak memiliki vegetasi yang sangat signifikan. Hal ini kemungkinan dapat disebabkan karena pada stasiun 1 merupakan area reklamasi sedangkan pada stasiun 2 tingkat abrasi yang terjadi terbilang cukup tinggi sehingga vegetasi hanya terdapat di area yang sangat jauh dari pantai sehingga kemungkinan penyu untuk dapat naik ke area tersebut sangat kecil.

\section{Suasana Pantai}

Menurut Pratiwi, (2016) Penyu merupakan salah satu hewan yang menyukai tempat dengan suasana yangenderung sepi dalam melakukan proses peneluran, hal ini disebabkan karena penyu memiliki kepekaan yang luar biasa terhadap gangguan pergerakan maupun penyinaran. Berdasarkan observasi lapangan yang telah dilakukan terhadap kedua stasiun yaitu pantai Serangan tergolong pantai yang sangat sepi dan pantai Saba tergolong pantai yang tergolong ramai. Hal ini dibuktikan dari banyaknya wisatawan yang datang ke pantai tersebut. Pantai Serangan merupakan salah satu pantai reklamasi yang ada di Denpasar, Bali. Terhitung sejak Maret 2018, hak akses ke pantai Serangan mulai dibatasi, alasan dari pembatasan hak akses tersebut masih belum jelas hingga tiba saatnya 
penelitian berakhir. Pantai Serangan merupakan pantai yang biasanya digunakan oleh instansi Turtle Conservation and Education Center dalam melakukan perilisian penyu. Semenjak adanya pembatasan hak akses, pantai Serangan jadi semakin jarang dikunjungi oleh wisatawan.

Pantai Saba merupakan pantai alami yang terdapat di desa Saba, Gianyar, Bali. Pantai Saba merupakan pantai di Gianyar yang aksesnya tidak dibatasi. Di pantai Saba juga tidak dipungut biaya apapun apabila wisatawan ingin mengunjungi pantai Saba. Sehingga pengunjung yang mendatangi pantai Saba terbilang cukup banyak. Kedua stasiun ini tidak dapat ditemukan data primer jumlah pengunjung yang konkrit, sehingga data yang digunakan dalam pembuktian analisa suasana pantai adalah data yang diperoleh dari pihak instansi konservasi yang melakukan perilisan penyu.

\section{Faktor Pendukung Lain}

Berdasarkan uraian inventarisir data yang telah tercakup dalam Tabel 2. sudah diuraikan hasil dari parameter yang menjadi bahan uji kesesuaian habitat peneluran penyu. Selain daripada parameter yang telah dianalisa terdapat parameter pendukung lain yang dapat mempengaruhi penyu naik ke permukaan untuk melakukan peneluran yaitu cahaya bulan. Mukminin (2002) mengatakan bahwa banyaknya penyu yang naik ke pantai saat bulan purnama lebih banyak dibandingkan saat bulan biasa. Pada 23 Juli - 31 Juli 2018 jumlah penyu yang naik lebih banyak dibandingkan dengan jumlah penyu yang naik pada bulan agustus. Hal ini disebabkan karena pada 23 juli - 31 juli termasuk dalam fase bulan penuh (Bulan Purnama). Diduga hal ini disebabkan karena reaksi dari naluri penyu terhadap cahaya bulan dengan panjang gelombang cahaya tertentu. Adapun factor penghambat dari area peneluran penyu ini adalah suasana pantai dimana suasana pantai yang menjadi area peneluran penyu haruslah sepi dengan aktivitas manusia yang sangat minim. Sehingga penyu dapat leluasa untuk naik ke pantai tanpa ada rasa khawatir akan hadirnya predator yang akan mempengaruhi aktivitas peneluran itu sendiri. Hal ini disebabkan karena penyu memiliki kepekaan yang tinggi terhadap pergerakan dari predator.

\section{Analisis Kesesuaian pantai Sebagai Area Konservasi Penyu}

Ketika musim kawin dan bertelur induk penyu memiliki karakteristik habitat guna membuat sarang sehingga induk penyu dapat bertelur dengan rasa aman dan nyaman. Umumnya induk penyu mulai bertelur pada malam hari hingga menjelenga fajar. Lama Penyu bertelur biasanya berkisar antara 1 -2 jam saja. Pada saat menetas, tukik yang selamat dan menjadi penyu dewasa akan mulai memijah pada usia 20 hingga 50 tahun dan selanjutnya akan melakukan migrasi ke daerah pakan untuk melakukan perkawinan. Menurut Nuitja, (1997) penyu betina yang telah dibuahi akan kembali ketempat dimana dia menetas untuk menaruh telur - telurnya. Penyu dalam 1 tahun dapat bertelur sebanyak 2 sampai 3 kali dengan interval waktu 10 hingga 14 hari. Selain daripada hal itu kegiatan peneluran penyui tidak dipengaruhi oleh hal - hal terkait dnegan polutan, arus dan kegiatan nelayan. Karena penyu hanya kembali ke daerah asal dimana dia menetas atau dirilis. Hal ini jugalah yang menyebabkan penyu sulit untuk di konservasi. Adapun parameter yang mempengaruhi induk penyu bertelur pada stasiun 1 dan 2 ditampilkan pada tabel 3.

Tabel 3. Form Penilaian Perbandingan Karakteristik Habitat Peneluran Penyu

\begin{tabular}{|c|c|c|c|}
\hline \multirow{2}{*}{\multicolumn{2}{|c|}{ Perbandingan Karakteristik Habitat }} & \multicolumn{2}{|c|}{ Stasiun } \\
\hline & & $\begin{array}{l}\text { Pantai } \\
\text { Serangan }\end{array}$ & Pantai Saba \\
\hline \multirow{4}{*}{ Parameter Kualitas Perairan } & Suhu $\left({ }^{\circ} \mathrm{C}\right)$ & $\sqrt{ }$ & $\sqrt{ }$ \\
\hline & Derajat Keasaman $(\mathrm{pH})$ & $\sqrt{ }$ & $\sqrt{1}$ \\
\hline & Oksigen terlarut $(\mathrm{mg} / \mathrm{l})$ & $\sqrt{ }$ & $\sqrt{ }$ \\
\hline & Salinitas (ppt) & $\sqrt{ }$ & $\sqrt{ }$ \\
\hline \multirow{5}{*}{ Parameter Habitat Penyu } & Panjang Pantai & $\sqrt{ }$ & $\sqrt{ }$ \\
\hline & Lebar Pantai & $\sqrt{ }$ & $\sqrt{ }$ \\
\hline & Kemiringan Pantai & $\sqrt{ }$ & $\sqrt{ }$ \\
\hline & Pasang Surut & $\sqrt{ }$ & $\sqrt{ }$ \\
\hline & Kedalaman Sarang & $\sqrt{ }$ & $\sqrt{ }$ \\
\hline
\end{tabular}




\begin{tabular}{lcc} 
Substrat & $\sqrt{ }$ & $\sqrt{ }$ \\
\hline Suhu Permukaan Sarang & $\sqrt{ }$ & $\sqrt{ }$ \\
\hline Suhu Kedalaman Sarang & $\sqrt{ }$ & $\sqrt{ }$ \\
\hline Suasana Pantai & $\sqrt{ }$ & $x$ \\
\hline Abrasi & $\sqrt{ }$ & $\sqrt{ }$ \\
\hline Vegetasi & $x$ & $x$
\end{tabular}

Berdasarkan analisa yang telah dilaksanakan, maka seara keseluruhan hasil yang diperoleh ditampilkan pada Tabel 3. dimana pada kedua stasiun maka dapat diketahui bahwa parameter yang menjadi faktor penghambat dari kedua stasiun memiliki kemiripan yaitu vegetasi. Pada kedua stasiun tidak ditemukan vegetasi yang signifikan yang memiliki peranan penting dalam melindungi telur dari suhu yang tinggi atau predator. Sehingga apabila hal ini terus menerus di biarkan dan telur - telur penyu tidak di tangani secara cepat maka kemungkinan akan mengalami kegagalan penetasan. . Selain daripada faktor tersebut, factor lain yang dianalisa masih cukup sesuai sebagai area konservasi untuk peneluran penyu. Dari kedua stasiun yang dianalisa tidak ada perbedaan yang cukup signifikan karena hampir seluruh faktor yang dianalisa memenuhi syarat sebagai area peneluran penyu

\section{KESIMPULAN DAN SARAN}

Parameter kualitas perairan berupa Suhu perairan pada stasiun 1 pada pagi hari sebesar $26,4^{\circ} \mathrm{C}$, Pada Sore hari berkisar $27,7^{\circ} \mathrm{C}$, sedangka pada stasiun 2 suhu perairan pada pagi hari berkisar $26,5^{\circ} \mathrm{C}$ dan sore hari sebesar $27,7^{\circ} \mathrm{C}$ dengan rata-rata sebesar di kedua perairan sebesar $27^{\circ} \mathrm{C}$, Derajat Keasaman $(\mathrm{pH})$ pada stasiun 1 pada pagi hari sebesar 7,9 , pada sore hari sebesar 8 pada stasiun 2 saat pagi hari sebesar 7,5 dan pada sore hari sebesar 7,8, untuk parameter oksigen terlarut pada stasiun 1 saat pagi hari sebesar $6,5 \mathrm{mg} / \mathrm{l}$ dan saat sore hari sebesar $5,55 \mathrm{mg} / \mathrm{l}$, pada stasiun 2 saat pagi hari sebesar $6,9 \mathrm{mg} / \mathrm{l}$ dan sore hari sebesar 5,6 mg/l, untuk salinitas pada stasiun 1 di pagi hari sebesar 30,8 ppt dan saat sore hari sebesar $33,1 \mathrm{ppt}$, pada stasiun 2 saat pagi hari sebesar 30,6 ppt dan sore hari sebesar 33,8 ppt. Berdasarkan Keputusan Menteri Lingkungan Hidup nomor 51 Tahun 2004 untuk area konservasi, kedua stasiun sudah sesuai.

Berdasarkan penelitian yang telah dilaksanakan di stasiun 2 yaitu pantai Saba, Pantai Saba sudah layak untuk dijadikan area konservasi penyu. Faktor yang menghambat kedua stasiun untuk menjadi area konservasi yang sesuai adalah keberadaan vegetasi dimana kedua stasiun tidak memiliki jumlah vegetasi yang sangat signifikan sebagai area peneluran penyu.

\section{DAFTAR PUSTAKA}

Anshary, M., Setyawati, T. R., \& Yanti, A. H. (2014). Karakteristik pendaratan penyu hijau (Chelonia mydas, Linnaeus 1758) di pesisir pantai Tanjung Kemuning Tanjung Api dan Pantai Belacan kecamatan Paloh kabupaten Sambas. Protobiont, 3(2)., 232-239.

Arianto, A. (2014). Studi Kondisi Biofisik Penyu di Kelurahan Koto Jaya, Kecamatan Kota Mukomuko, Kabupaten Mukomuko Propinsi Bengkulu. Skripsi. Padang: Fakultas Perikanan dan IImu Kelautan, Universitas Bung Hatta.

Ario, R., Wibowo, E., Pratikto, I., \& Fajar, S. (2016). Pelestarian Habitat Penyu Dari Ancaman Kepunahan Di Turtle Conservation And Education Center (TCEC), Bali. Jurnal Kelautan Tropis, 19(1), 60-66.

Booth, D. T., Burgess, E., McCosker, J., \& Lanyon, J. M. (2004, December). The influence of incubation temperature on post-hatching fitness characteristics of turtles. In International Congress Series (Vol. 1275, pp. 226-233). Elsevier.

Effendi, H. (2003). Telaah Kualitas Air: Bagi pengelolaan dan Sumberdaya Lingkungan Perairan. Yogyakarta, Indonesia: Kanisius.

Mukminin, A. (2002). Studi Habitat Peneluran Penyu Hijau (Chelonia mydas, L) di Pulau Sangalaki, Kepulauan Derawan, Kabupaten Berau, Kalimantan Timur. Bogor: Institut Pertanian Bogor (Skripsi).

Nuitja, I., \& Uchida, S. (1982). Preliminary Studies on the Growth and Food Consumption of the Juvenile Loggerhead Turtle, Carreta carreta L. Aquaculture, 27, 157-160.

Pratiwi, B. (2016). Keragaman Penyu dan Karakteristik Habitat Penelurannya di Pekon Muara Tembulih, Ngambur, 
Pesisir Barat. Skripsi. Bandar Lampung: Fakultas Pertanian, Universitas Lampung.

Putera, A. A., Sulmartiwi, L., \& Tjahjaningsih, W. (2015). Pengaruh Kedalaman Sarang Penetasan Penyu Hijau (Chelonia mydas) terhadap masa inkubasi dan Persentase Keberhasilan Penetasan Di Pantai Sukamade, Taman Nasional Meru Betiri, Banyuwangi, Jawa Timur. Jurnal IImiah Perikanan dan Kelautan, 7(2), 195-198.

Ridwan, E. A., Sara, L., Asriyana. (2017). Karakteristik biofisik habitat peneluran Penyu Hijau (Chelonia mydas) di Pantai Kampa, Konawe Kepulauan. Jurnal Manajemen Sumber Daya Perairan. 2(4), 295-305

Rofiah, A., Hartati, R., \& Wibowo, E. (2012). Pengaruh Naungan Sarang Terhadap Presentase Telur Penyu Lekang (Lepidochyles olivacea) di Pantai Samas Bantul, Yogyakarta. Journal Of Marine Researh, 1(2), 313-318.

Rohim, H., Rifanjani, S., \& Erianto. (2017). Studi habitat tempat bertelur penyu Hjau (Chelonia mydas) di kawasan Tambling Wildlife Nature Conservation (TWNC) Taman Nasional Bukit Barisan Selatan (TNBBS) Tanggamus Pesisir Barat. Jurnal Hutan Lestari, 5, 313-318.

Sepawan, Mat. (2017). Pengaruh Struktur Dan Komposisi Vegetasi Pantai Terhadap Pendaratan Penyu (Cheloniodea) Di Pekon Muara Tembulih Keamatan Ngambur Kabupaten Pesisir Barat. Skripsi.Universitas Islam Negeri Raden Intan Lampung:Lampung

Setiawan, R., \& Zamdial, d. F. (2018). Studi Karakteristik Habitat Peneluran Penyu di Desa Pekik Nyaring Keamatan Pondok Kelapa, Kabupaten Bengkulu Tengah, Provinsi Bengkulu. Jurnal IImu Kelautan Kepulauan, I(1), 59-70.

Simanjuntak, M. (2012). Kualitas Air Laut Ditinjau Dari Aspek Zat Hara, Oksigen Terlarut dan $\mathrm{pH}$ diperairan Banggai, Sulawesi Tenggara. Jurnal IImu dan Teknologi Kelautan Tropis, 4(2), 290303.

Susana, T. (2009). Tingkat keasaman $(\mathrm{pH})$ dan Oksigen Terlarut Sebagai Indikator Kualitas Perairan Sekitar Muara Sungai isadane. Jurnal Teknologi Lingkungan, 5(2), 33-39. 